\title{
Multilocus DNA fingerprints in gallinaceous birds: general approach and problems
}

\author{
O. HANOTTE,* M. W. BRUFORD $†$ \& T. BURKE \\ Department of Zoology, University of Leicester, Leicester LE1 7RH, U.K. and *Laboratoire de Biochimie Molèculaire, \\ Facultè de Médecine, Université de Mons-Hainaut, 7000 Mons, Belgique
}

\begin{abstract}
Multilocus profiles were investigated in five different species of Galliformes (ring-necked pheasant Phasianus colchicus, Indian peafowl Pavo cristatus, Japanese quail Coturnix coturnix japonica, domestic chicken Gallus gallus, and red grouse Lagopus lagopus scoticus) using two human multilocus probes (33.6 and 33.15) in combination with each of four restriction enzymes (AluI, DdeI, HaeIII or HinfI). All the species show a DNA fingerprint-like pattern using at least one restriction enzyme in combination with each multilocus probe. The number of bands detected and the value of the index of similarity for each species differ significantly between the profiles obtained with each multilocus probe. Some enzyme/probe combinations reveal strong cross-hybridization of the multilocus probes with satellite or satellite-like DNA sequences in pheasant, peacock, quail and chicken, which partially or completely prevented scoring of the profile. The choice of restriction enzyme was found to influence the number of bands, the value of the index of similarity and the probability of obtaining an identical fingerprint between unrelated individuals. The Mendelian inheritance and independent segregation of the fragments detected using AluI was investigated in three species (ring-necked pheasant, Indian peafowl and red grouse). Some bands were shown to be tightly linked. An extreme case was encountered in the red grouse, where 12 of the 15 bands scored in one parent represented only two, apparently allelic, haplotypes and so derived from a single locus. However, fingerprint patterns will often be adequate for use in paternity analyses, such as in behavioural studies, despite the occurrence of haplotypic sets of bands. Identical DNA multilocus profiles were sometimes observed between captive-bred siblings in one species. These results emphasize the desirability of determining, in each new species, the optimal experimental conditions as a preliminary to any behavioural or population genetic studies that use the multilocus DNA fingerprinting methodology.
\end{abstract}

Keywords: gallinaceous birds, 33.6, 33.15, minisatellite, multilocus DNA fingerprints, segregation analysis.

\section{Introduction}

The discovery in human DNA of hypervariable regions (Wyman \& White, 1980), also called minisatellite sequences (Jeffreys et al., 1985a) or VNTR (variable number of tandem repeats, Nakamura et al., 1987b), led to the establishment of the multilocus DNA fingerprinting technique (Jeffreys et al., 1985b). This allowed important new developments in areas as diverse as forensic science (Gill et al., 1985), behavioural ecology (e.g. Burke, 1989; Burke et al., 1989; Birkhead et al.,

†Present address: Institute of Zoology, Regent's Park, London NW1 4RY, U.K.

Correspondence: T. Burke, Department of Zoology, University of Leicester, Leicester LE1 7RH, U.K.
1990) and animal breeding (Hillel et al., 1989; Kuhnlein et al., 1989; Bruford et al., 1990).

Minisatellites consist of tandem repeats of a short, typically 10-60 bp, DNA sequence. The high level of polymorphism observed at these loci results from differences in the number of repeats between alleles. There are sets of minisatellite loci among which each individual repeat unit shares a more or less identical 'core' sequence (Jeffreys et al., 1985a). Several different 'core' sequences associated with different, nonexclusive sets of minisatellite loci have been characterized (Jeffreys et al., 1985a; Vassart et al., 1987; Fowler et al., 1988). The hybridization at low stringency of digested genomic DNA, with probes consisting of tandem repeats of a 'core' sequence, allows 
the detection of multiple minisatellite loci in a wide variety of animals and plants (e.g. Burke \& Bruford, 1987; Jeffreys \& Morton, 1987; Hoelzel \& Amos, 1988; Dallas, 1988; Georges et al., 1988; Fowler et al., 1988; Taggart \& Ferguson, 1990; see Burke et al., 1991a for reviews), generating a DNA 'fingerprint' pattern (Jeffreys et al., 1985a).

A multilocus DNA 'fingerprint' has two main properties. Firstly, the DNA fingerprint of an individual shows Mendelian inheritance; on average an individual will receive half of its bands from each parent (Jeffreys et al., 1985a). Secondly, the probability that two unrelated individuals will present the same multilocus pattern is generally many orders of magnitude smaller than the reciprocal of the population size (Jeffreys et al., 1985a; Burke et al., 1991b). However, these properties are dependent upon the bands detected in an individual fingerprint being in linkage equilibrium. The most likely source of disequilibrium is linkage between loci. The simplest way to exclude this possiblity is to analyse the segregation of bands in a large family of the species under study (Burke, 1989). This analysis is generally preceded by a determination of the experimental conditions (restriction enzyme/multilocus probe combination) needed to obtain a DNA fingerprint pattern showing the best compromise between maximizing the number of scorable bands and minimizing the band-sharing among unrelated individuals (Burke, 1989). So far, such an analysis has been carried out in only a small number of animal species; in mammals: human (Jeffreys et al., 1986; Fowler et al., 1988), Mus (Jeffreys et al., 1987), dog Canis familiaris and cat Felis catus (Jeffreys \& Morton, 1987); in birds: house sparrow Passer domesticus (Burke \& Bruford, 1987; Wetton \& Parkin, 1989); dunnock Prunella modularis (Burke et al., 1989), domestic chicken Gallus gallus (Bruford, et al., 1990) and zebra finch Taeniopygia guttata (Birkhead et al., 1990).

We have recently been investigating the application of multilocus and single locus DNA fingerprinting in the Galliformes (Bruford et al., 1990; Hanotte et al., $1991 \mathrm{a}, \mathrm{b})$. This order of birds includes several species of commercial interest (Bruford \& Burke, 1991), and the typically large broods of 10-15 offspring (Johnsgard, 1986) are helpful in genetic studies; the Galliformes also have a variety of mating systems and include classic examples of phenotypic and sexual selection (Darwin, 1871). We have also begun studies of the molecular evolution of minisatellite loci in this group (Hanotte et al., 1991a,b).

In this paper, we use five species of Galliformes (ring-necked pheasant Phasianus colchicus, Indian peafowl Pavo cristatus, Japanese quail Coturnix coturnix japonica, domestic chicken, and red grouse
Lagopus lagopus scoticus) to illustrate the general approach underlying a multilocus DNA fingerprinting analysis in a new species. The results will then be compared with the data obtained in other animals and will be discussed in the context of our knowledge of the genomic organization and molecular characterization of avian minisatellites.

\section{Materials and methods}

Blood samples $(50-200 \mu \mathrm{l})$ were collected by venipuncture from birds belonging either to wild or first generation captive bird populations (red grouse and ring-necked pheasant), or from birds kept in captivity for several generations (domestic chicken, Indian peafowl and Japanese quail). The ring-necked pheasant, the chicken, the Indian peafowl and the Japanese quail are generally included in the same family, the Phasianidae (Johnsgard, 1986), while the red grouse belongs to the family Tetraonidae.

The protocols used to obtain multilocus fingerprints are described in detail elsewhere (Birkhead et al., 1990; Bruford et al., 1992). Briefly, the genomic DNA was extracted and purified after an overnight incubation with proteinase $\mathrm{K}$, either by two phenol/ chloroform purifications and one chloroform/isoamyl alcohol extraction (Burke \& Bruford, 1987) or by precipitation of the proteins in high salt solution (Miller et al., 1988). Five micrograms of DNA from each sample was restricted overnight with 15 units of restriction enzyme (AluI, DdeI, HaeIII or HinfI) in the buffer provided by the supplier (BRL), and in the presence of $4 \mathrm{~mm}$ spermidine trihydrochloride (Sigma). The digested DNA was extracted once with phenol/chloroform, ethanol precipitated, and resuspended in TE (10 mM Tris, $1 \mathrm{~mm}$ EDTA, $\mathrm{pH}$ 7.5). The DNA fragments were separated in a 0.8 or 1.0 per cent horizontal agarose gel (Sigma, Type I in TBE buffer: 0.089 м Tris-borate, $\mathrm{pH}$ 8.8, 2 mм EDTA) until the 2.3-kb marker band of lambda DNA cut with HindIII had migrated approximately $17 \mathrm{~cm}(20 \mathrm{~cm}$ long gel) or $19 \mathrm{~cm}(30 \mathrm{~cm}$ long gel). Pedigree analyses were carried out in $30-\mathrm{cm}$ gels to obtain maximum band separation; all other gels were $20 \mathrm{~cm}$ long. The gels were then capillary blotted onto nylon membrane (Hybond-N, Amersham). [ $\left.\alpha^{32} \mathrm{P}\right] \mathrm{dCTP}$-labelled minisatellite probes 33.6 and 33.15 were prepared from M13 recombinants by primer extension (Jeffreys et al. 1985a,b). The same prehybridization, hybridization and washing conditions were applied to all Southern blots hybridized to both multilocus probes in each species. The filters were prehybridized for at least $3 \mathrm{~h}$ at $64^{\circ} \mathrm{C}$ in a solution containing 7 per cent SDS, $1 \mathrm{~mm}$ EDTA, 0.263 м Na phosphate, pH 7.2 and 1 per cent 
bovine serum albumin (Sigma, fraction V) (Church \& Gilbert, 1984; Westneat et al., 1988). The probe was added in the same solution and hybridizations were carried out overnight at $64^{\circ} \mathrm{C}$. The filters were successively washed at the same temperature, once for $15 \mathrm{~min}$ in $0.263 \mathrm{M} \mathrm{Na}$ phosphate $\mathrm{pH} 7.2,1$ per cent SDS, twice for $25 \mathrm{~min}$ in $2 \times \mathrm{SSC}, 0.1$ per cent SDS and three times for $25 \mathrm{~min}$ in $1 \times \mathrm{SSC}, 0.1$ per cent SDS. They were then autoradiographed for $2-7$ days at $-70^{\circ} \mathrm{C}$ using Fuji RX or Amersham MP X-ray film and one or two intensifying screens.

Bands were scored either throughout the length of the gel $(20 \mathrm{~cm}$ gel) or until crowding of the low molecular weight bands prevented any scoring $(30 \mathrm{~cm}$ gel). The coefficient of band sharing (index of similarity) was calculated as $x=2 n_{\mathrm{ab}} /\left(n_{\mathrm{a}}+n_{\mathrm{b}}\right)$ where $n_{\mathrm{a}}$ and $n_{\mathrm{b}}$ are the numbers of bands present in individuals $a$ and $b$ respectively, and $n_{\mathrm{ab}}$ is the number of bands shared by $\mathrm{a}$ and b (Wetton et al., 1987; Hanotte et al., 1991a). Only bands which migrated to the same distance (in practice within $0.5 \mathrm{~mm}$ ) and which showed no more than a two fold intensity difference were considered to be shared (Bruford et al., 1992). Bands shared between parents were excluded from pedigree analyses, although where adjacent bands had a greater than twofold intensity difference the band of higher intensity was included. The Mendelian transmission and independent segregation of the bands were studied after excluding all but one of each haplotypic set of apparently tightly linked bands (bands always transmitted together), or of each pair of apparently allelic bands (bands always transmitted as alternatives); apparently homozygous parental bands were excluded (Bruford et al., 1992). The observed transmission frequency and linkage distributions were compared with the expected binomial distribution for unlinked loci.

\section{Results}

\section{The effect of enzyme/probe combination}

Each combination of four restriction enzymes (AluI, DdeI, HaeIII or HinfI) and two human multilocus probes (33.6 and 33.15) was tested in five different species of Galliformes (red grouse, ring-necked

Table 1 Intraspecific similarities of band patterns produced by the human multilocus probes 33.6 and 33.15 in the Galliformes

\begin{tabular}{|c|c|c|c|c|c|c|c|c|}
\hline \multirow[b]{3}{*}{ Species } & \multicolumn{8}{|l|}{ Enzyme } \\
\hline & \multicolumn{2}{|l|}{ AluI } & \multicolumn{2}{|l|}{$D d e I$} & \multicolumn{2}{|l|}{ HaeIII } & \multicolumn{2}{|l|}{ HinfI } \\
\hline & $n \pm$ s.d. & $x \pm$ s.d. & $n \pm$ s.d. & $x \pm$ s.d. & $n \pm$ s.d. & $x \pm$ s.d. & $n \pm$ s.d. & $x \pm$ s.d. \\
\hline \multicolumn{9}{|c|}{ 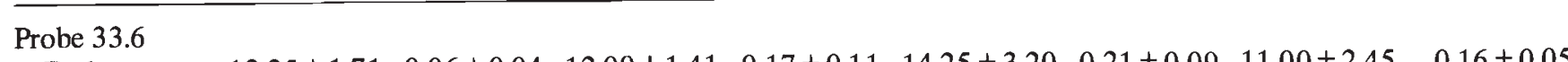 } \\
\hline Red grouse & $12.25 \pm 1.71$ & $0.06 \pm 0.04$ & $12.00 \pm 1.41$ & $0.17 \pm 0.11$ & $14.25 \pm 3.20$ & $0.21 \pm 0.09$ & $11.00 \pm 2.45$ & $0.16 \pm 0.05$ \\
\hline Pheasant & $19.00 \pm 3.46$ & $0.11 \pm 0.06$ & $25.34 \pm 2.08$ & $0.13 \pm 0.09$ & $12.34 \pm 2.52$ & $0.25 \pm 0.14$ & $24.66 \pm 3.05$ & $0.23 \pm 0.15$ \\
\hline Quail & $12.33 \pm 5.03$ & 0.27 & $12.33 \pm 3.79$ & 0.52 & $17.33 \pm 0.58$ & 0.45 & $16.33 \pm 2.08$ & 0.51 \\
\hline Chicken & $14.67 \pm 3.21$ & $0.29 \pm 0.07$ & $11.33 \pm 2.52$ & $0.29 \pm 0.03$ & $15.00 \pm 2.00$ & $0.15 \pm 0.07$ & $29.33 \pm 0.58$ & $0.21 \pm 0.05$ \\
\hline Peafowl & $23.34 \pm 3.21$ & $0.45 \pm 0.07$ & $24.00 \pm 3.46$ & $0.41 \pm 0.08$ & $17.67 \pm 3.51$ & $0.33 \pm 0.09$ & $29.00 \pm 4.36$ & $0.51 \pm 0.06$ \\
\hline \multicolumn{9}{|c|}{ ( } \\
\hline Red grouse & $34.25 \pm 3.59$ & $0.28 \pm 0.04$ & $35.00 \pm 2.16$ & $0.29 \pm 0.04$ & $30.75 \pm 2.16$ & $0.22 \pm 0.07$ & $32.25 \pm 2.22$ & $0.26 \pm 0.08$ \\
\hline Pheasant & $34.67 \pm 2.08$ & $0.63 \pm 0.03$ & $24.67 \pm 0.58$ & $0.73 \pm 0.06$ & $33.67 \pm 4.04$ & $0.73 \pm 0.06$ & $31.33 \pm 5.51$ & $0.71 \pm 0.10$ \\
\hline Quail & $34.33 \pm 6.35$ & 0.58 & - & - & $20.67 \pm 2.08$ & 0.70 & - & - \\
\hline Chicken & - & - & - & - & $32.00 \pm 2.65$ & $0.32 \pm 0.15$ & - & - \\
\hline Peafowl & $34.00 \pm 1.00$ & $0.48 \pm 0.10$ & $33.00 \pm 2.65$ & $0.39 \pm 0.05$ & $33.67 \pm 1.53$ & $0.34 \pm 0.04$ & $38.67 \pm 3.5$ & $0.42 \pm 0.02$ \\
\hline \multicolumn{9}{|c|}{ Probabilities } \\
\hline 33.6 v. $33.15^{*}$ & 0.016 & 0.048 & 0.071 & 0.250 & 0.008 & 0.191 & 0.071 & 0.357 \\
\hline$n$ v. $x \ddagger$ & 0.0 & & & & & & & \\
\hline
\end{tabular}

$n$ refers to the mean number of bands scored in three or four individuals. $x$ is the index of similarity. It was calculated from one (quail), three (pheasant, chicken, peafowl) or four (red grouse) pairwise comparisons (see Fig. 1 legend). - indicates that it was not possible to score the gel (see text). *Two-tailed probabilities for permutation test (Siegel \& Castellan, 1988) comparison between the sets of mean values obtained with each probe. $¥$ Two-tailed probabilities from Spearman’s correlation coefficients, both probes combined. 
pheasant, Japanese quail, Indian peafowl and domestic chicken). The mean number of bands per individual, $n$ $(N=3-4)$, and the index of similarity, $x$, between pairwise comparisons $(n=1-4)$ of unrelated individuals run in adjacent lanes are indicated in Table 1 for each scorable combination. The similarity values have been treated as independent in the calculation of the standard deviations, although some fingerprints contributed to two similarity values. The expected probabilities of two unrelated birds having identical DNA fingerprints, under the assumption that the bands are independent and in linkage equilibrium, are presented in Table 2. Some of the DNA fingerprint patterns obtained are illustrated in Fig. 1a and b.

Using probe 33.6 , we observed a scorable DNA fingerprint-like pattern in each species for each restriction enzyme used (e.g. Fig. 1a and b; Table 1). In each case, well-separated fragments showing variable intensities and interindividual variation were detected. However, probe 33.6 hybridizes intensively to several high molecular weight fragments $(\geq 9.6 \mathrm{~kb}$ ) in genomic DNA of the Indian peafowl cut with AluI and Hinfl (Fig. 1a), obscuring any DNA fingerprint pattern in this region of the gel. In each species, the multilocus patterns obtained with probe 33.15 clearly differed from those detected with 33.6, although the same hybridization and washing conditions were used. In all but one case, the ring-necked pheasant digested with $D d e I$, there were characteristically more bands detected by 33.15 than by 33.6 (Table 1). Moreover, probe 33.15 often hybridizes more intensively to the higher molecular weight fragments than to the lower ones (Figs 1b, 4b and 5b). In the chicken, a high number of badly separated bands prevents any scoring of the fragments when the genomic DNA is cut with the restriction enzymes DdeI, Hinfl and $A l u \mathrm{I}$ and probed with 33.15 (Fig. 1b). Taking the values for permutation tests for each enzyme (Table 1) yields a significant mean probability of 0.04 , reflecting very little overlap in the number of bands detected by each probe (Fig. 2). In the Japanese quail, the hybridization patterns with probe 33.15 and Hinfl or AluI show a dark smear, obscuring any underlying fingerprint bands. Up to three times more bands are detected in the red grouse, with 33.15 than with 33.6 (Table 1), and the fragments detected by 33.15 appear to be more equally distributed (not shown).

The band-sharing coefficient between unrelated birds is usually higher for 33.15 than for 33.6. In this case the mean of the permutation probabilities (Table 1) is not significant, reflecting a large degree of overlap between the ranges of values obtained with each probe. The difference, however, is particularly important in the ring-necked pheasant; for example, the same pairs of birds showed similarities as distinct as $0.11 \pm 0.06$ and $0.63 \pm 0.03$ when the genomic DNA was cut with $A l u \mathrm{I}$ and probed with 33.6 and 33.15 respectively (Table 1 ). The choice of restriction enzyme influences the number of bands detected as well as the value of the index of similarity. However, the two parameters show a high degree of concordance among enzymes within species (taking the eight complete rows in Table 1 ,

Table 2 Expected probability of identity of DNA fingerprints in five species of Galliformes*

\begin{tabular}{lllll}
\hline & \multicolumn{2}{l}{ Enzymes } & & \\
\cline { 2 - 5 } Species & AluI & DdeI & HaeIII & HinfI \\
\hline Probe 33.6 & & & & \\
Red grouse & $1.2 \times 10^{-15}$ & $5.8 \times 10^{-10}$ & $2.0 \times 10^{-10}$ & $1.8 \times 10^{-9}$ \\
Pheasant & $6.1 \times 10^{-19}$ & $3.8 \times 10^{-23}$ & $3.9 \times 10^{-8}$ & $1.7 \times 10^{-16}$ \\
Quail & $1.0 \times 10^{-7}$ & $3.2 \times 10^{-4}$ & $1.0 \times 10^{-7}$ & $1.7 \times 10^{-5}$ \\
Chicken & $1.3 \times 10^{-8}$ & $8.4 \times 10^{-7}$ & $4.4 \times 10^{-13}$ & $1.3 \times 10^{-20}$ \\
Peafowl & $8.3 \times 10^{-9}$ & $5.1 \times 10^{-9}$ & $3.1 \times 10^{-9}$ & $3.3 \times 10^{-9}$ \\
Probe 33.15 & & & & \\
Red grouse & $1.1 \times 10^{-19}$ & $1.5 \times 10^{-19}$ & $6.0 \times 10^{-21}$ & $1.3 \times 10^{-19}$ \\
Pheasant & $1.1 \times 10^{-7}$ & $4.2 \times 10^{-4}$ & $2.5 \times 10^{-5}$ & $2.2 \times 10^{-5}$ \\
Quail & $7.7 \times 10^{-9}$ & - & $1.0 \times 10^{-3}$ & - \\
Chicken & - & - & $1.5 \times 10^{-16}$ & - \\
Peafowl & $1.5 \times 10^{-11}$ & $3.2 \times 10^{-14}$ & $1.6 \times 10^{-16}$ & $2.6 \times 10^{-15}$ \\
\hline
\end{tabular}

*Calculated as $x^{n}$ where $x=$ the mean band sharing coefficient and $n=$ the mean number of bands (Table 1). $-=$ detection of satellite-like sequences. 


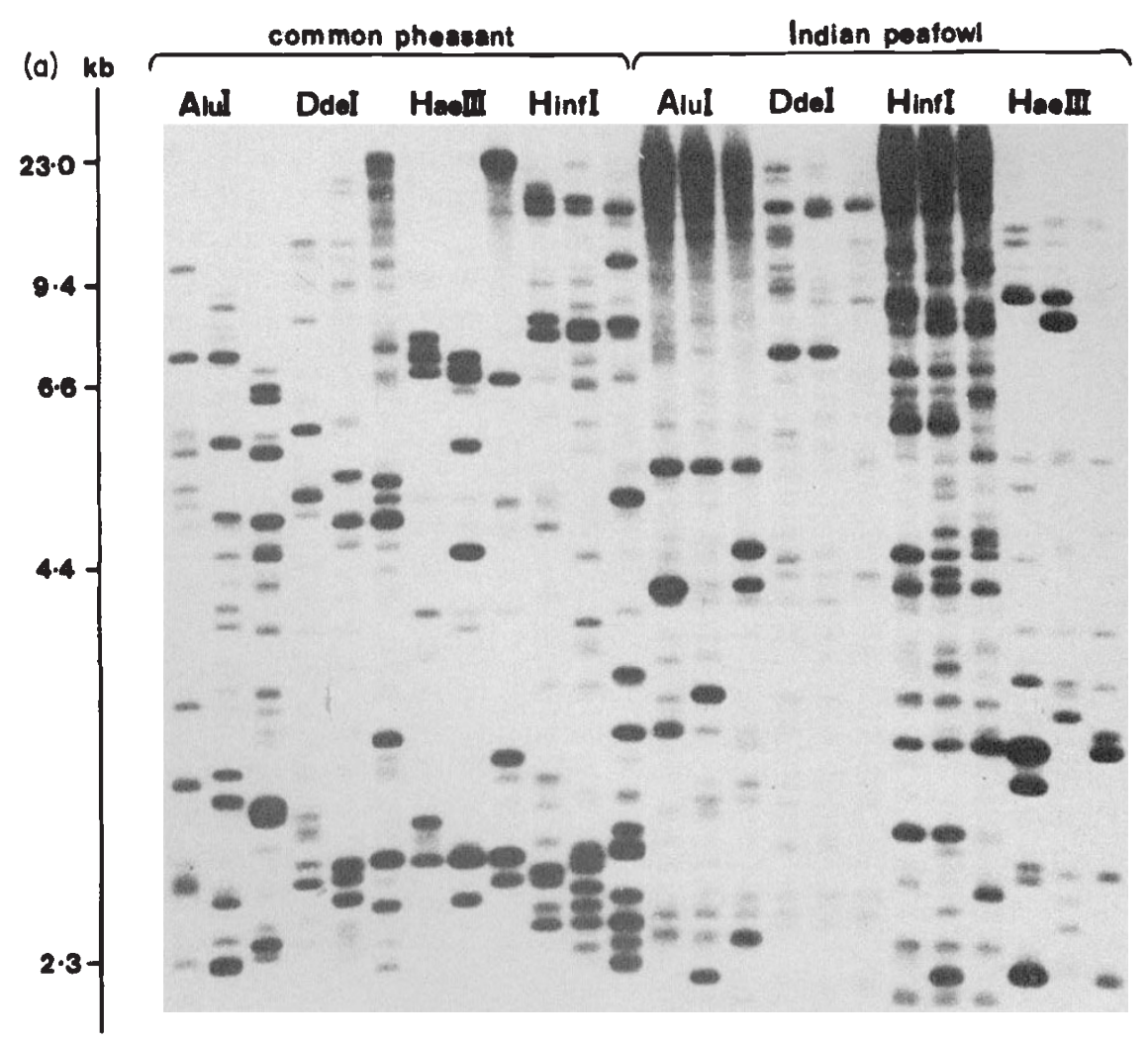

Fig. 1 The genomic DNA of five species of Galliformes was digested with four restriction enzymes (AluI, DdeI, HaeIII and HinfI) and hybridized with the human-derived multilocus probes $33.6(\mathrm{a})$ or 33.15 (b). Three unrelated ring-necked pheasant (a), Indian peafowl (a) and domestic chicken (b), and a pair $(2,3)$ of Japanese quail and their offspring (1) (b), were loaded in the gels.
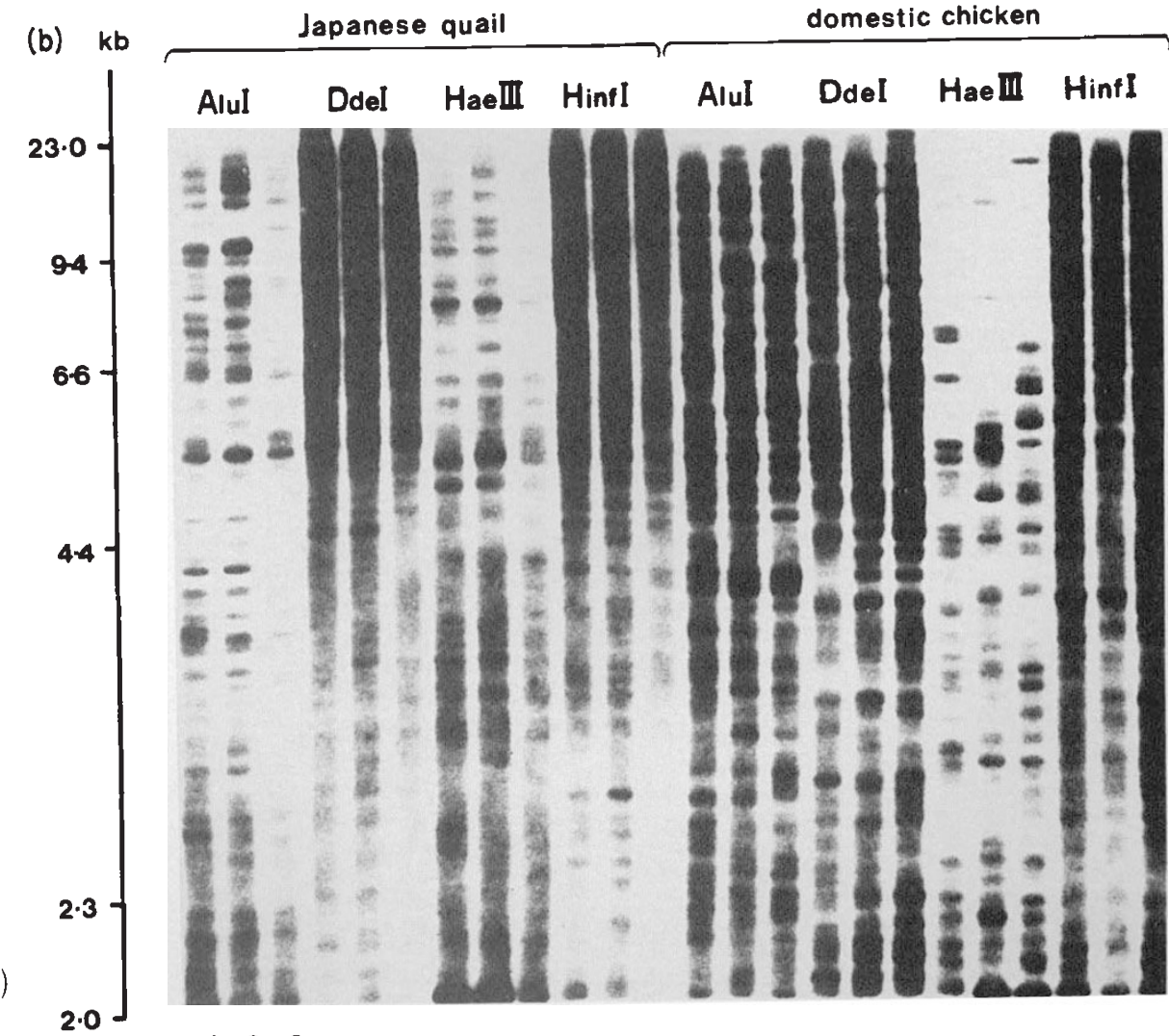

123 
Kendall coefficients of concordance: for $n, W=0.79$, $P=0.003$; for $x, W=0.82, \quad p=0.002$ ), suggesting that there may be considerable overlap among the sets of DNA fragments detected using different restriction enzymes (although the fragments will vary in absolute size due to varying flanking sequence length).

It might have been expected that there would be a relationship between the number of bands and the band-sharing coefficient, as the more crowded the fingerprint is, the higher the chance that non-allelic fragments will appear to have the same electrophoretic mobility. However, only the data from $A l u \mathrm{I}$ provided support for such a correlation $(P=0.02)$ and the mean probability across all four enzymes was not significant $(P=0.38)$ (Table 1$)$.

From the mean number of fragments and the mean band-sharing coefficient we can estimate the probability that two unrelated individuals will have an identical fingerprint as $x^{n}$ (Jeffreys et al., 1985b) (Table 2). The values obtained should usually be conservative, assuming that the component fragments are independent entities, i.e. that there is no disequilibrium, and therefore no linkage or allelism amongst the fragments. This assumption will not always be justified (see below). The probabilites obtained with 33.15 and with 33.6 often differ greatly but there is no significant overall difference between the estimates obtained with each probe. In the ring-necked pheasant the difference obtained using the probes is particularly large; for example, using the restriction enzyme DdeI the probability of obtaining an identical DNA fingerprint pattern is $4.2 \times 10^{-4}$ and $3.5 \times 10^{-23}$ for 33.6 and
33.15 respectively (Table 2 ). We can also compare the probability of identity between two unrelated individuals (Table 2) with the index of similarity or the number of bands (Table 1). We note that the same level of band sharing may yield a very different probability of identity, depending on the mean number of fragments scored in an individual (e.g. red grouse DNA cut with DdeI and probed with 33.15 compared with chicken DNA cut with DdeI and probed with 33.6). Finally, for the same probe but using different restriction enzymes, the order of magnitude of the probability of identity may vary by a factor of nearly three within the same species (e.g. chicken or pheasant probed with 33.6).

\section{Mendelian inheritance and independence of the fingerprint bands}

The Mendelian inheritance and independent segregation of the fragments detected in low stringency hybridization experiments with probes 33.6 and 33.15 were assessed using large pedigrees.

In the red grouse, a large family including both parents and 12 offspring of known sex was studied (Fig. 3). The genomic DNA was cut with the restriction enzyme AluI. From the restriction enzyme/probe combination tests, we expected to detect a fingerprint pattern showing several strongly hybridizing bands (data not shown) and a low band-sharing coefficient between unrelated individuals for both multilocus probes (Table 1). Using 33.6, the resolved bands were scored in the size range $1.8-23.0 \mathrm{~kb}$ (Fig. 3). Sixteen

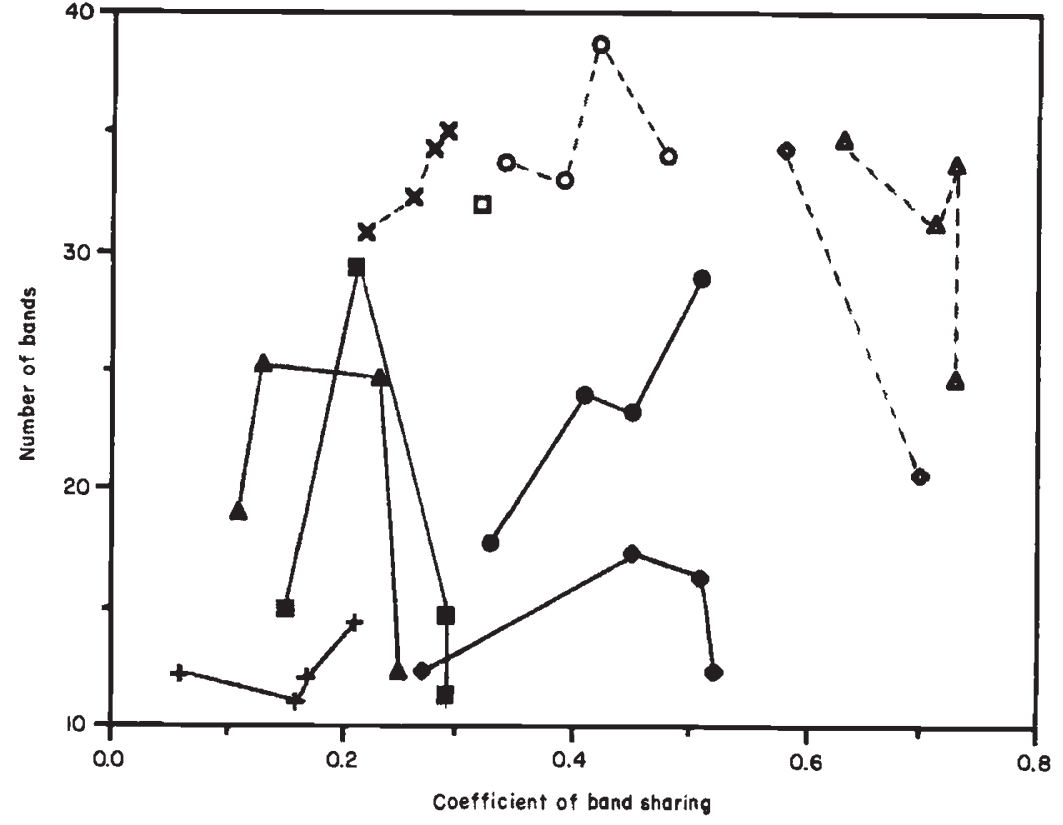

Fig. 2 Relationships between the number of bands and band-sharing coefficient. Data from the same species are connected by solid lines (33.6) or broken lines (33.15) to aid interpretation. $(\bullet$, , c) Chicken, $(\bullet, 0)$ peafowl, $(\boldsymbol{\Delta}, \Delta)$ pheasant, $(\bullet, \diamond)$ quail, $(+, \times)$ red grouse. 
bands were scored in the male and 20 bands in the female. Only one band was apparently shared by the two parents (so $x=0.06$ ); this band was excluded from the segregation analysis. Analysis of the pedigree indicated that all parental fragments were heterozygous and that none of the loci was sex-linked. However, analysis of the transmission of the fragments revealed several cases of allelism and tightly linked bands (Table 3, Fig. 3). For 12 offspring the probability that any specific pair of unlinked parental fragments would fortuitously segregate as if linked or allelic is $0.5^{11}$. From the 19 maternal fragments, six co-segregated into the offspring. Whether or not these fragments result from the presence of an internal cleavage site for $A l u \mathrm{I}$ in one large minisatellite (total length $>24.0 \mathrm{~kb}$ ) or constitute several different closely linked minisatellites is not known. A fragment which is apparently allelic to this co-segregating haplotype was also detected $(\sim 2$ $\mathrm{kb})$. The segregation of the 13 loci was consistent with that expected for a recombination frequency of 50 per cent (data not shown). The 15 paternal fragments included a set of nine which co-segregated (total length $\geq 20.0 \mathrm{~kb}$ ) and appeared to be allelic to a different set of three co-segregating fragments (total length $\geq 15.7$ $\mathrm{kb})$. The total number of paternal loci analysed was therefore only 4 , and the number of maternal loci analysed was 13 .

Using the multilocus probe 33.15 a completely different pattern is detected. Resolved bands were scored in the range $1.7-23.0 \mathrm{~kb}$. For the estimation of the band-sharing coefficient between the parents, 33 bands were scored in the female and 35 in the male, of which 12 were shared between the adults to give a value for $x$ of 0.35 . The segregation of 17 fragments was studied in each parent; the faint and badly resolved bands in addition to the bands shared between the parents were excluded. All the bands were found to be heterozygous except for one presumably homozygous paternal band (the probability that any one of the 35 heterozygous bands would appear to be homozygous by chance is only $\left.0.5^{12} \times 35=8.5 \times 10^{-3}\right)$. The remaining 33 loci showed a mean transmission frequency of
Fig. 3 Red grouse fingerprints from two adults (M: male, F: female) and their 12 offspring ( $\mathrm{m}$ : male, f: female) detected with probe 33.6. The genomic DNA was cut with the restriction enzyme $A l u \mathrm{I}$ and the fragments were scored in the size range $1.8-23.0 \mathrm{~kb}$. Co-segregating heterozygous maternal $(\triangleright)$ and paternal $(\Delta)$ bands are joined by continuous lines; allelic pairs are joined by broken lines.

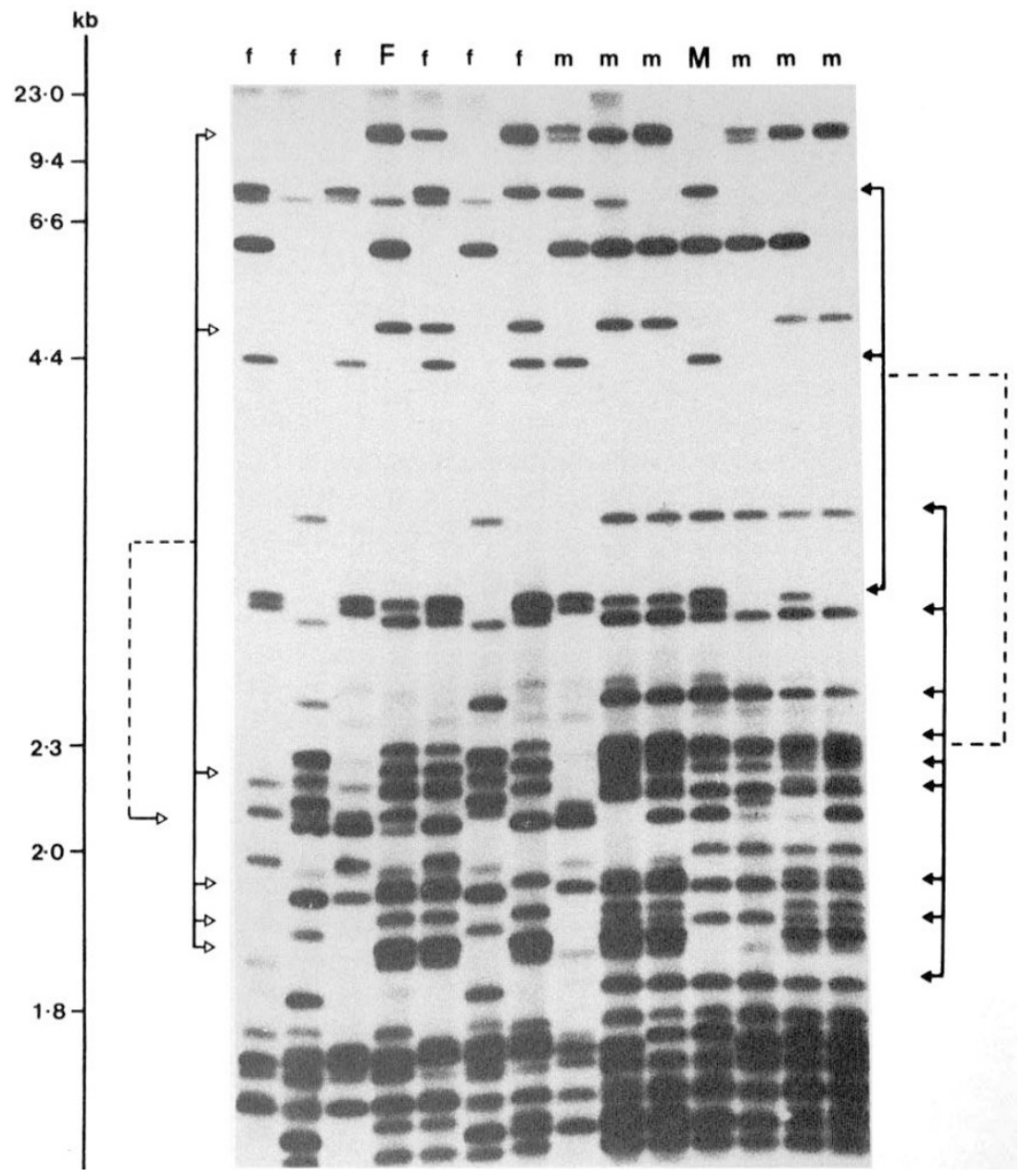


Table 3 Summary of the DNA fragments detected in red grouse, ring-necked pheasant and Indian peafowl families

\begin{tabular}{|c|c|c|c|c|c|c|}
\hline & \multicolumn{2}{|c|}{ Red grouse } & \multicolumn{2}{|c|}{ Ring-necked pheasant } & \multicolumn{2}{|c|}{ Indian peafowl } \\
\hline & Female & Male & Female & Male & Female & Male \\
\hline \multicolumn{7}{|l|}{ Probe 33.6} \\
\hline Bands scored & 20 & 16 & 40 & 25 & 18 & 21 \\
\hline Bands shared & 1 & 1 & 4 & 4 & 17 & 17 \\
\hline Bands analysed & 19 & 15 & 35 & 19 & 1 & 9 \\
\hline Homozygotes & 0 & 0 & 0 & 0 & 1 & 9 \\
\hline Allelic pairs & $1^{*}$ & 1 & $1^{*}$ & 1 & - & - \\
\hline Linked bands & $6^{*}$ & $9+3$ & $10^{*}$ & 3 & - & - \\
\hline Total loci analysed & 13 & 4 & 25 & 16 & 1 & 9 \\
\hline \multicolumn{7}{|l|}{ Probe 33.15} \\
\hline Bands scored & 33 & 35 & 31 & 28 & 22 & 26 \\
\hline Bands shared & 12 & 12 & 16 & 16 & 20 & 20 \\
\hline Bands analysed & 17 & 17 & 10 & 8 & 2 & 5 \\
\hline Homozygotes & 0 & 1 & 0 & 0 & 0 & 0 \\
\hline Allelic pairs & 1 & 0 & 1 & 2 & 0 & 0 \\
\hline Linked bands & 0 & 0 & 2 & 3 & 0 & 0 \\
\hline Total loci analysed & 16 & 17 & 8 & 4 & 2 & 5 \\
\hline
\end{tabular}

*Haplotype of several bands allelic to a single band.

0.53 , not significantly different from the Mendelian expectation of 0.50 . In the female, there was one case of apparent allelism between a pair of fragments. In both the male and the female the segregation of the loci was consistent with that expected for a recombination frequency of 50 per cent (data not shown). None of the fragments was sex-linked.

Some fragments appeared from their size to be detected by both multilocus probes in the parents but each was found to be transmitted independently to the offspring and consequently there was no overlap between the profiles obtained with each multilocus probe. No fragment specific to 33.6 was found to be allelic or closely linked to a fragment specific to 33.15 . The sets of bands detected using each probe were therefore independent.

A similar pedigree analysis was carried out in a large family of ring-necked pheasants which contained 10 offspring of unknown sex (Table 3, Fig. 4a and b). The genomic DNA was cut with $A l u \mathrm{I}$ and the fragments were scored in the size range $1.6-23 \mathrm{~kb}$ for 33.6 and 33.15. With 33.6, 40 bands were scored in the female and 25 in the male, four of which were shared (so $x=0.12$ ). Segregation was studied for 35 fragments in the female and 19 fragments in the male. All the bands appeared to be heterozygous but two sets of cosegregating bands were detected (Fig. 4a). Ten bands were transmitted together in the female. As in the red grouse, this could result from the presence of an internal cleavage site for $A l u \mathrm{I}$ in a large minisatellite (total length $>30 \mathrm{~kb}$ ) or constitute several different closely linked minisatellites. This large haplotype seems to be allelic to one fragment of approximately $1.8 \mathrm{~kb}$ length. The paternal-specific bands included three co-segregating fragments and one allelic pair. Consequently, 35 bands represented 25 independent loci in the female and 19 bands represented 16 independent loci in the male; the segregation of these 25 and 16 loci was consistent with that expected for a recombination frequency of 50 per cent (data not shown). The mean transmission frequency was 0.54 , close to the Mendelian expectation of 0.50 . Two offspring showed an extra band not present in either parent; this suggests a rate of electrophoretically detectable length mutation of approximately $7 \times 10^{-3}$ (total number of bands scored $=286$ ). Probe 33.15 hybridizes more strongly to the higher molecular weight fragments than to the lower ones (Fig. 4b). Thirty-one fragments were scored in the female and 21 in the male, for which $x=0.53$. The segregation of 10 maternal and eight paternal bands was studied (Fig. $4 \mathrm{~b})$. In the female, one pair of allelic bands was detected and two bands co-segregated. In the male, two pairs of allelic bands were detected, one including a haplotype of three bands. Thus, the eight fragments scored in the male belong to only four loci (Table 3 ). Again, there is 
no overlap between the multilocus probes, and the sets of fragments detected by each probe segregate independently.

The two multilocus fingerprint patterns obtained in our Indian peafowl pedigree exhibit a very low level of variability between individiuals (Table 3 , Fig. 5a and b). This pedigree derives from a small captive breeding population that has been genetically isolated for several generations. The band-sharing coefficient between the two parents is 0.77 for probe 33.6 , with 18 and 26 fragments scored in the mother and the father respectively. We could follow the transmission of one maternal-specific fragment and nine paternal-specific fragments but all of them were apparently homozygous. Consequently, the four offspring present an identical multilocus DNA 'fingerprint' for all the frag- ments scored (Fig. 5a). The probability of a heterozygous band being transmitted to all of four offspring is relatively high at $1 / 16$ per locus but this is significantly unlikely to be able to account for the observed pattern for more than a few fragments. Moreover, close inspection of the autoradiograph discloses that these bands are approximately half as intense in the offspring as in the parents (Fig. 5a). We can, then, reasonably suppose that these bands were all homozygous in the parents. For probe 33.15, $x=0.83$, with 22 bands scored in the female and 26 in the male. We scored only two maternal-specific bands and five paternal-specific bands. However, at least six of these seven bands were heterozygous; using probe 33.15 , each offspring showed a distinct multiband pattern (Fig. 5b). Not more than three bands were detected by both probes;
Fig. 4 Multilocus fingerprints from one large ring-necked pheasant pedigree including the two parents $(\mathrm{M}$ : male, F: female) and five of their 10 offspring. The genomic DNA was cut with the restriction enzyme $A l u \mathrm{I}$ and the fragments were scored in the size range $1.6-23.0 \mathrm{~kb}$ after hybridization with the probes $33.6(\mathrm{a})$ and $33.15(\mathrm{~b})$. Co-segregating heterozygous maternal $(\triangleright)$ and paternal $(\triangleleft)$ bands are joined by continuous lines; allelic pairs are joined by broken lines. Two mutant bands are indicated by arrows.

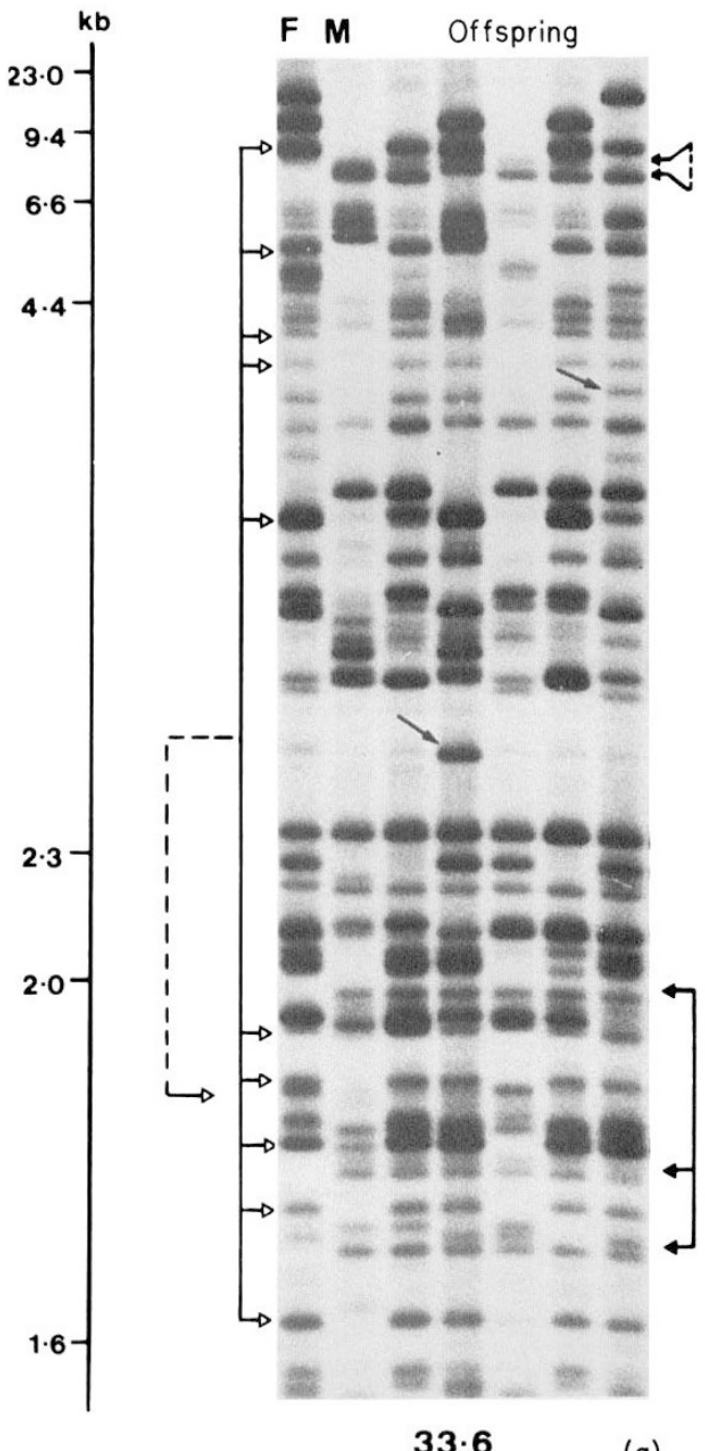

$33 \cdot 6$

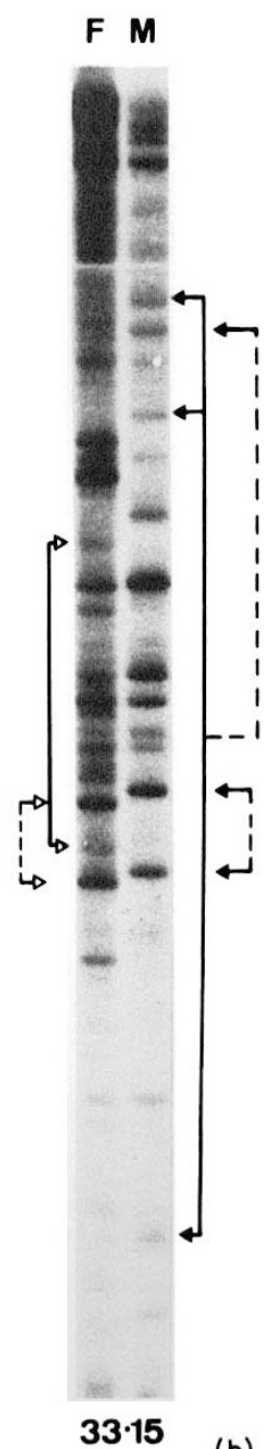

(b) 


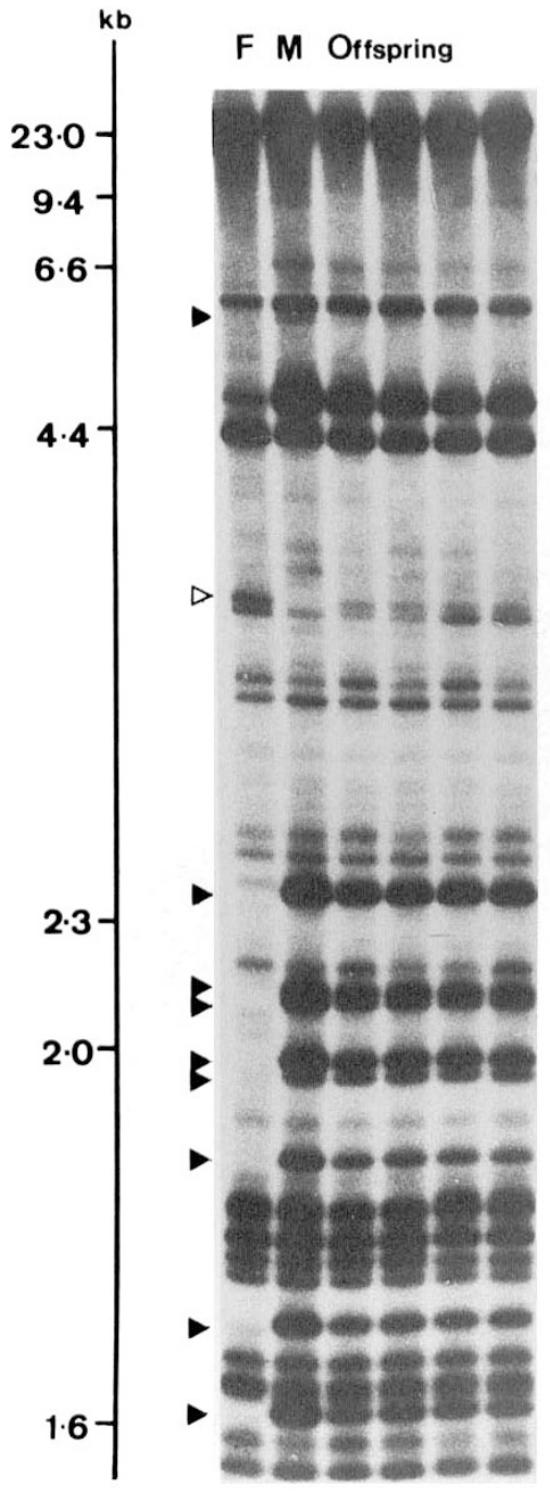

$33 \cdot 6$

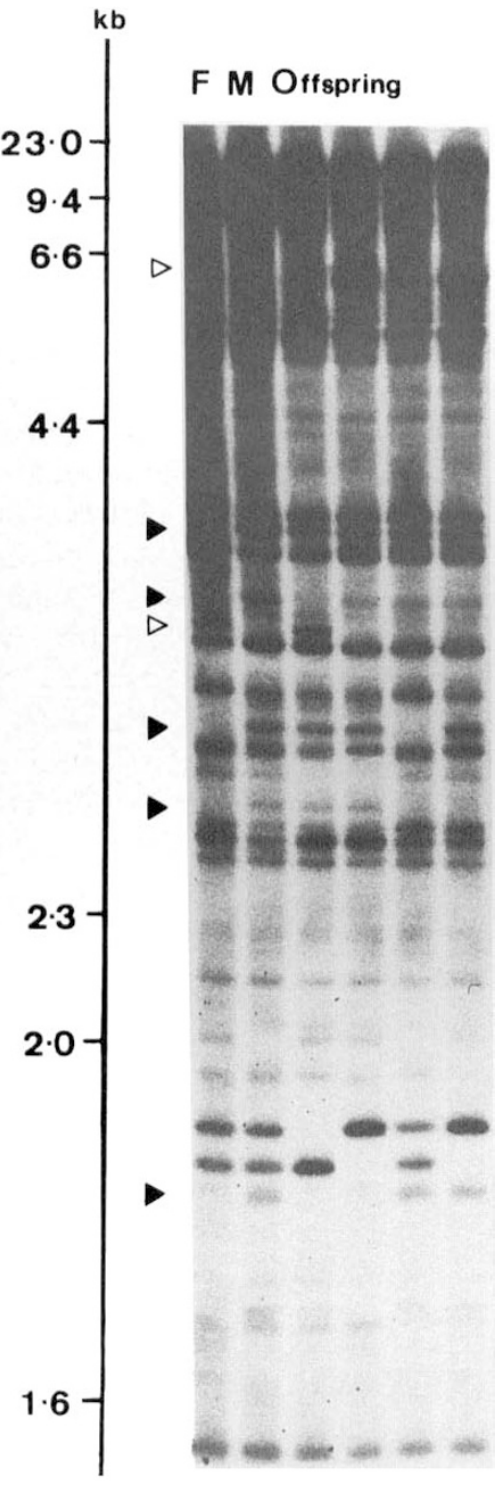

$33 \cdot 15$

(a)

(b)

Fig. 5 Indian peafowl fingerprints from two adults (M: male, F: female) and four offspring detected with probe $33.6(\mathrm{a})$ and $33.15(\mathrm{~b})$. The fragments were scored in the size range 1.6-23 $\mathrm{kb}$. ( $\triangleright$ ) Maternal-specific bands $(\rightarrow)$ paternal-specific bands. Using the multilocus probe 33.6 , all the offspring show an identical multiband pattern. as each occurred in all of the offspring we cannot tell whether they actually represented the same loci.

\section{Discussion}

A recommended preliminary step to any study using multilocus DNA fingerprint analysis in a new species is the determination of the best enzyme/probe combination (Burke, 1989; Bruford et al., 1992). Three factors have to be considered: (i) the general characteristics of the multiband pattern (electrophoretic resolution between the fragments, and intensity of the signal), (ii) the mean number of bands present in an individual, and (iii) the value of the index of similarity between unrelated individuals. The independent segregation of the fragments can then ideally be tested in a large pedigree for the selected enzyme/multilocus probe combination. We analysed the usefulness of this approach in five species of gallinaceous birds.

There is often a compromise to be made between scoring many bands and maintaining a low coefficient of band sharing, although we show above that there is no overall inverse correlation between these two 
variables. We therefore suggest using the expected identity between individuals, $x^{n}$, as a measure of the 'power' of a fingerprint when deciding which combination of factors is of most value. The mean value for $x^{n}$ varies enormously among probe/enzyme combinations, even within a species (Table 2 ). If a paternity or relatedness study is being planned, estimation of the mean probability of false inclusion, $x^{n(1-x) / 2}$, might be an even better guide to the best system to use, especially for species in which $x$ varies greatly among probe/enzyme combinations (e.g. ring-necked pheasant, Table 1).

Digestion with some enzymes produces strong cross-hybridization of the multilocus probe 33.15 with abundant sequences present in domestic chicken and Japanese quail DNA cut with different restriction enzymes (Fig. 1b). Such cross-hybridization was only previously reported in the Japanese quail for the restriction enzyme HinfI (Burke \& Bruford, 1987) and in cattle Bos bovis where the multilocus probe 33.15 cross-hybridizes strongly to a bovine satellite DNA (Jeffreys, 1987). These new observations, and others from the multilocus screening of avian libraries, in which cross-hybridizations between multilocus probes and satellite sequences are common (Burke. et al., 1991b), suggest that the detection of satellite or satellite-like sequences by the probes 33.6 and $33.15 \mathrm{might}$ be more common than previously thought.

The electrophoretic multiband patterns obtained with each multilocus probe are clearly different (Figs $1 \mathrm{c}$ and $\mathrm{d}, 3-5$, Table 1). Moreover, no band was detected with both probes in the red grouse and ringnecked pheasant pedigree analyses (Figs 3-5). So, in these two species of Galliformes, as in other species of birds (e.g. house sparrow, Burke \& Bruford, 1987; zebra finch Birkhead et al., 1990) and in human (Jeffreys et al., 1986), very few, if any, minisatellites hybridize to both 33.6 and 33.15 , indicating that these human polycore probes also detect different sets of minisatellite loci in these birds. This situation contrasts with that found in the dog where approximately 23 per cent of the minisatellite loci are detected by both probes (Jeffreys \& Morton, 1987).

The number of bands hybridizing with 33.15 and 33.6 (Table 1) and the total number of loci scored (Table 3 ) suggest that the two sets of minisatellites are not equally frequent in the genomes of gallinaceous birds. Pedigree analysis (treating apparently haplotypic sets of bands as single alleles) indicates that these two sets of loci are dispersed.throughout the genome (data not shown). This dispersion has also been found to exist in several species of passerines (Burke \& Bruford, 1987; Burke et al., 1989; Birkhead et al., 1990). However, the haplotypic patterns observed in the red grouse and the ring-necked pheasant might reflect tight clustering among a proportion of loci, rather than restriction sites within relatively long minisatellite (or 'midisatellite', Nakamura et al., 1987a) arrays (see below). Indeed, linkage groups of fingerprint bands have been described in large pedigrees of human (Wells et al., 1989) and cattle (Georges et al., 1990), and in situ hybridization studies have shown the propensity of minisatellites to be located in the telomeric regions of chromosomes in human (Royle et al., 1988). Such chromosomal studies have still to be carried out in birds before we can discover whether there is clustering of minisatellite loci on the macro- and/or microchromosomes.

In our red grouse pedigree, where the sexes of the offspring were known, no sex-linked fragments were detected. Until recently, only one sex-linked minisatellite had been noted in any species (Jeffreys et al., 1987), but Rabenold et al. (1991) have since reported the presence of female-specific bands in 33.15 multilocus fingerprints of the stripe-backed wren Campylorhynchus nuchalis, and the screening of a human genomic library (Armour et al., 1990) as well as a chicken genomic library (Bruford \& Burke, 1991) with 33.15 and 33.6, respectively, has led to the isolation of $X$ and $\mathrm{Z}$ chromosome-specific minisatellite loci. In addition, using the multilocus probe M13, Longmire et al. (1991) detected sets of fragments that are only present in the DNA of females of species belonging to the genus Falco.

The ring-necked pheasant shows a particularly high level of band sharing using multilocus probe 33.15 compared with the result obtained with 33.6 (Table 1). A similar situation has been found in a wild population of minke whales Balaenoptera acutorostrata (van Pijlen et al., 1991) and might reflect the detection of haplotypic patterns with 33.15 or a different mean mutation rate for the sets of loci detected by each of the multilocus probes.

The use of different restriction enzymes in the same species produces multilocus patterns in which the bands differ in intensity, number and electrophoretic distribution (Table 1, Fig. 1a and b). In molecular terms, the difference in the intensities of the bands within a fingerprint reflects different levels of similarity between the multilocus probe and the detected minisatellite locus (Nakamura et al., 1987b). The variation observed in the number and distribution of bands reflects variation in the frequency at which different restriction sites occur. Consequently, the length of the flanking sequence will vary, and if a particular restriction enzyme cuts within some or all of the repeats within a minisatellite a set of haplotypic fragments will result, which may be smaller than the smallest frag- 
ments resolved in the fingerprints. These possibilities can, however, be demonstrated if a minisatellite locus can be specifically identified using a single locus probe (Nakamura et al., 1987b; Hanotte et al., 1991b). We have detected several haplotypes in our pedigree analyses including three allelic pairs (Table 3, Fig. 3 and Fig. $4 \mathrm{a}$ ) and we cannot distinguish between the possibilities that they belong to different closely linked minisatellite loci or that they derive from one large minisatellite. Such large minisatellites $(>20 \mathrm{~kb})$ would derive from loci having alleles of particularly variable size, as it has been shown in the red grouse and the ring-necked pheasant that the allelic band to these large haplotypes is approximately $2 \mathrm{~kb}$ long (Figs 3 and 4a).

The presence of large haplotypes within multilocus fingerprints has been previously described in several species. A large haplotype of fragments totalling approximately $60 \mathrm{~kb}$, perhaps corresponding to a single minisatellite with internal HaeIII restriction sites, has been detected in a mute swan Cygnus olor pedigree (Meng et al., 1990). In the dog, Jeffreys \& Morton (1987) suggest that five co-segregating fragments are derived from a $>80-\mathrm{kb}$ long minisatellite containing internal Hinfl cleavage sites. However, the situation appears to be extreme in the red grouse when $A l u \mathrm{I}$ and 33.6 are used in combination; between 37 and 80 per cent of the bands per fingerprint were found to belong to one single locus (Table 3, Fig. 3). In the ring-necked pheasant, using the same conditions, 11 ( 31 per cent) of the bands scored in the female and 5 ( 26 per cent) in the male correspond to one and two loci respectively (Table 3, Fig. 4a). The occurrence of such a high level of linkage was rather unexpected. It emphasizes the importance of completing an analysis of a large pedigree before applying fingerprints in the analysis of paternity or relatedness in a new species. For example, the probability that all the bands scored in our male red grouse are also present in a random individual is only of the order of $x^{5}$ rather than the $x^{16}$ which might naively have been expected from the number of bands. More significantly, the number of paternal-specific alleles in his offspring may often be very low indeed, on occasion as few as zero $(P=0.016)$, so the reliability of paternity analyses might be relatively low. However, our best estimate of the mean number of paternalspecific bands per offspring is $(12+4) / 2$, for which the mean expected probability of false inclusion would still be relatively small, but adequate for most studies, at $0.5^{8}=0.004$. This likelihood can, of course, be reduced still further by using two probes. Recently, Westneat (1990), in a study of the indigo bunting Passerina cyanea, and F. M. Hunter et al. (1992), in a study of the northern fulmar Fulmarus glacialis, used the observed distributions of band sharing values betwen known relatives and non-relatives to test hypotheses concerning the relatedness of other individuals in the absence of segregation data. It is too early to evaluate this approach as no comparative study between the methods has as yet been carried out.

In two species (Indian peafowl and Japanese quail), band-sharing coefficients for non-relatives were higher than generally observed in a wild population of birds (e.g. Burke \& Bruford, 1987; Birkhead et al., 1990) (Table 1). While the sample size was small and the data have to be considered with caution, these values are likely to reflect a significant degree of inbreeding in these captive populations. It has been shown in chicken (Kuhnlein et al., 1989), California Channel Island foxes Urocyon littoralis (Gilbert et al., 1990), and naked mole-rats Heterocephalus glaber (Reeve et al., 1990) that low levels of variability in multilocus fingerprints reflect elevated levels of inbreeding. Such a situation also occurred in our Indian peafowl pedigree, where the parents shared around 80 per cent of their bands for both multilocus probes and where the offspring showed an identical DNA fingerprint with multilocus probe 33.6.

\section{Acknowledgements}

This work was supported by grants from NERC, SERC and the Royal Society to TB. We greatly thank Professor A.O.A. Miller for his constant encouragement. Blood samples were kindly provided by Professor P. Bateson, Mr J. Corder, Dr N. Hillgarth, Dr R. Moss, Mr Q. Spratt, Antwerp Zoo (Mr R. Van Bocxstaele), the Game Conservatory ( $\mathrm{Dr} \mathrm{D}$. Potts), Institut de Sélection Animale (Dr M. Smiley), and the World Pheasant Association (Mr T. Gardiner). We would also like to thank Professor Alec Jeffreys for providing the minisatellite probes, Lesley Barnett and Ian Riddell for assistance with figure preparation and Iris van Pijlen for helpful comments on the manuscript.

\section{References}

ARMOUR, J. A. L., POVEY, S., JEREMIAH, S. AND JEFFREYS, A. J. 1990. Systematic cloning of human minisatellites from ordered array charomid libraries. Genomics, 8, 501-512.

BIRKHEAD, T. R., BURKE, T., ZANN, R., HUNTER, F. M. AND KRUPA, A. P. 1990. Extra-pair paternity and intraspecific brood parasitism in wild zebra finches Taeniopygia guttata, revealed by DNA fingerprinting. Behav. Ecol. Sociobiol., 27, 315-324.

BRUFORD, M. AND BURKE, T. 1991. Hypervariable DNA markers and their applications in the chicken. In: Burke, T., Dolf, G., Jeffreys, A. J. and Wolff, R. (eds) DNA Fingerprinting. 
Approaches and Applications, Birkhäuser Verlag, Basel, pp. 230-242.

BRUFORD, M. W., BURKE, T., HANOTTE, O. AND SMILEY, M. 1990. Hypervariable markers in the chicken genome. Proceedings of the 4th World Congress on Genetics Applied to Livestock Production, XIII, 139-142.

BRUFORD, M., HANOTTE, O., BROOKFIELD, J. F. Y. AND BURKE, T. 1992. Single locus and multilocus DNA fingerprinting. In: Hoelzel, A.R.(ed.) Molecular Genetic Analysis of Populations: a Practical Approach, IRL Press, Oxford, pp. 225-269.

BURKE, T. 1989. DNA fingerprinting and other methods for the study of mating success. Trends Ecol. Evol., 4, 139-144.

BURKE, T. AND BRUFORD, M. w. 1987. DNA fingerprinting in birds. Nature, Lond., 32 7, 149-152.

BURKE, T., DAVIES, N. B., BRUFORD, M. W. AND HATCHWELL, B. J. 1989. Parental care and mating behaviour of polyandrous dunnocks Prunella modularis related to paternity by DNA fingerprinting. Nature, Lond., 338, 249-251.

BURKE, T., DOLF, G., JEFFREYS, A. J. AND WOLFF, R. (eds) 1991a. DNA Fingerprinting: Approaches and Applications, Birkhäuser Verlag, Basel.

BURKE, T., HANOTTE, O., BRUFORD, M. W. AND CAIRNS, E. $1991 \mathrm{~b}$. Multilocus and single locus minisatellite analysis in population biological studies. In: Burke. T., Dolf, G., Jeffreys, A. J. and Wolff, R. (eds) DNA Fingerprinting: Approaches and Applications, Birkhäuser Verlag, Basel, pp. 154-168.

CHURCH, G. M. AND GILBERT, w. 1984. Genomic sequencing. Proc. Natl. Acad. Sci., U.S.A., 81, 1991-1995.

DALLAS, J. F. 1988. Detection of DNA 'fingerprints' of cultivated rice by hybridization with a human minisatellite DNA probe. Proc. Natl. Acad. Sci., U.S.A., 85, 6831-6835.

DARWIN, c. 1871. The Descent of Man, and Selection in Relation to Sex. J. Murray, London.

FOWLER, S. J., GILL, P., WERRETT, D. J. AND HIGGS, D.R. 1988. Individual specific DNA fingerprints from a hypervariable region probe: alpha-globin $3^{\prime} \mathrm{HVR}$. Hum. Genet., 79 , 142-146.

GEORGES, M., LATHROP, M., HILBERT, P., MARCOTTE, A., SCHWERS, A., SWILLENS, S., VASSART, G., AND HANSET, R. 1990. On the use of DNA fingerprints for linkage studies in cattle. Genomics, 6, 461-474.

GEORGES, M., LEQUARRE, A.-S., CASTELLI, M., HANSET, R. AND VASSART, G. 1988. DNA fingerprinting in domestic animals using four different minisatellite probes. Cytogenet. Cell. Genet., 47, 127-131.

GILBERT, D. A., LEHMAN, N., O'BRIEN, S. J. AND WAYNE, R. K. 1990. Genetic fingerprinting reflects population differentiation in the California Channel Island fox. Nature, Lond., 244, 764-766.

GiLL, P., JEFFREYS, A. J. AND WERRETT, D. J. 1985. Forensic applications of DNA 'fingerprints'. Nature, Lond., 318, 577-579.

HANOTTE, O., BURKE, T., ARMOUR, J. A. L. AND JEFFREYS, A. J. 1991 a. Hypervariable minisatellite DNA sequences in the Indian peafowl Pavo cristatus. Genomics, 9, 587-597.

HANOTTE, O., BURKE, T., ARMOUR, J. A. L. AND JEFFREYS, A. J. 1991 b.
Cloning, characterization and evolution of Indian peafowl Pavo cristatus minisatellite loci. In: Burke, T., Dolf, G., Jeffreys, A. J. and Wolff, R. (eds) DNA Fingerprinting: Approaches and Applications, Birkhäuser Verlag, Basel, pp. 193-216.

HILLEL, J., SCHAAP, T., HABERFELD, A., LAVI, U., CAHANER, A. AND JEFFREYS, A. J. 1989. DNA fingerprints of poultry. Anim. Genet., 20, 145-155.

HOELZEL, A. R. AND AMOs, w. 1988. DNA fingerprinting and scientific whaling. Nature, Lond., 314, 67-73.

HUNTER, E. M., BURKE, T. AND WATTS, S. A. 1992. Frequent copulation as a method of paternity assurance in the northern fulmar, Fulmarus glacialis. Anim. Behav. (in press).

JEFFREYS, A. J. 1987. Highly variable minisatellites and DNA fingerprints. Biochem. Soc. Trans., 15, 309-317.

JEFFREYS, A. J. AND MORTON, D. B. 1987. DNA fingerprints of dogs and cats. Anim. Genet., 18, 1-15.

JEFFREYS, A. J., WILSON, V., KELLY, R., TAYLOR, B. A. AND BULFIELD, G. 1987. Mouse DNA 'fingerprints': analysis of chromosome localization and germ-line stability of hypervariable loci in recombinant inbred strains. Nucl. Acids. Res., 14, 4605-4616.

JEFFREYS, A. J., WILSON, V. AND THEIN, S. L. 1985a. Hypervariable 'minisatellite' regions in human DNA. Nature, Lond., 314, 67-73.

JEFFREYS, A. J., WILSON, v. AND THEIN, S. L. 1985 b. Individualspecific 'fingerprints' of human DNA. Nature, Lond., 316, 76-79.

JEFFREYS, A. J., WILSON, V., THEIN, S. L., WEATHERALL, D. J. AND PONDER, B. A. J. 1986. DNA 'fingerprints' and segregation analysis of multiple markers in human pedigrees. Am. $J$. Hum. Genet., 39, 11-24.

Johnsgard, P. A. 1986. The Pheasants of the World. Oxford University Press, New York.

KUHNLEIN, U., DAWE, Y., ZADWORNY, D. AND GAVORA, J. S. 1989. DNA fingerprinting: a tool for determining genetic distances between strains of poultry. Theor. Appl. Genet., 77, 669-672.

LONGMIRE, J. L., AMBROSE, R. E., BROWN, N. C., CADE, T. J., MAECHTLE, T. L., SEEGAR, W. S., WARD, F. P. AND WHITE, C. M. 1991. Use of sex-linked minisatellite fragments to investigate genetic differentiation and migration of North American populations of the peregrine falcon (Falco peregrinus). In: Burke, T., Dolf, G., Jeffreys, A. J., and Wolff, R. (eds) DNA Fingerprinting: Approaches and Applications, Birkhäuser Verlag, Basel, pp. 217-229.

MENG, A., CARTER, R. E. AND PARKIN, D. T. 1990. The variability of DNA fingerprints in three species of swan. Heredity, 64, 73-80.

MILLER, S. A., DYKES, D. D. AND POLESKY, H. F. 1988. A simple salting out procedure for extracting DNA from human nucleated cells. Nucl. Acids Res., 16, 1215.

NAKAMURA, Y., JULIER, C., WOLFF, R., HOLM, T., O'CONNELl, P., LEPPERT, M. AND WHITE, R. 1987a. Characterization of a human 'midisatellite' sequence. Nucl. Acids Res., 15, 2537-2547.

NAKAMURA, Y., LEPPERT, M., O'CONNELL, P., WOLFF, R., HOLM. T., CULVER, M., MARTIN, C., FUJIMOTO, E., HOFF, M., KUMLIN, E. AND WHITE, R. $1987 \mathrm{~b}$. Variable number of tandem repeat 
(VNTR) markers for human gene mapping. Science, 235, 1616-1622.

RABENOLD, P. P., PIPER, W. H., DECKER, M. D. AND MINCHELLA, D. J. 1991. Polymorphic minisatellite amplified on avian W chromosome. Genome, 34, 489-493.

REEVE, H. K., WESTNEAT, D. F., NOON, W. A., SHERMAN, P. W. AND AQUADRO, C. F. 1990. DNA 'fingerprinting' reveals high levels of inbreeding in colonies of the eusocial naked mole rat. Proc. Natl. Acad. Sci., U.S.A., 87, 2496-2500.

ROYLE, N. J., CLARKSON, R. E., WONG, Z. AND JEFFREYS, A. J. 1988. Clustering of hypervariable minisatellites in the proterminal region of autosomes. Genomics, 3, 352-360.

SIEGEL, S. AND CASTELlan, N. J. 1988. Nonparametric Statistics for the Behavioural Sciences. 2nd edn. McGraw-Hill, London.

TAGGART, J. B. AND FERGUSON, A. 1990. Minisatellite DNA fingerprints of salmonid fishes. Anim. Genet., 21, 377-389.

VAN PIJLEN, I. A., AMOS, W. AND DOVER, G. A. 1991. Multilocus DNA fingerprinting applied to population studies of the minke whales Balaenoptera acutorostrata. Rep. Int. Whal. Commn., (Special issue 13), 245-254.

VASSART, G., GEORGES, M., MONSIEUR, R., BROCAS, H., LEQUARRE, A. S., AND CHRISTOPHE, D. 1987. A sequence in M13 phage detects hypervariable minisatellites in human and animal DNA. Science, 235, 683-684.

WELLS, R. A., GREEN, P. AND REEDERS, S. T. 1989. Simultaneous genetic mapping of multiple human minisatellite sequences using DNA fingerprinting. Genomics, 5, 761-772.

WESTNEAT, D. F. 1990 . Genetic parentage in the indigo bunting: a study using DNA fingerprinting. Behav. Ecol. Sociobiol., 27, 67-76.

WESTNEAT, D. F., NOON, W. A., REEVE, H. K. AND AQUADRO, C. F. 1988. Improved hybridization conditions for DNA 'fingerprints' probed with M13. Nucl. Acids. Res., 16, 4161.

WETTON, J. H., CARTER, R. E., PARKIN, D. T. AND WALTERS, D. 1987. Demographic study of a wild house sparrow population by DNA 'fingerprinting'. Nature, Lond., 327, 147-149.

WETTON, J. H. AND PARKIN, D. T. 1989. Genetic fingerprinting of house sparrows, Passer domesticus. In: Loxdale, H. D. and den Hollander, J. (eds) Electrophoretic Studies on Agricultural Pests, Systematics Association Special Vol. No. 39. Clarendon Press, Oxford, pp. 375-391.

WYMAN, A. R. AND WHITE, R. 1980 . A highly polymorphic locus in human DNA. Proc. Natl. Acad. Sci., U.S.A., 77, 6754-6758. 